\title{
CORRIGENDUM
}

\section{Idd13 is involved in determining immunoregulatory DN T-cell number in NOD mice}

V Dugas, A Liston, EE Hillhouse, R Collin, G Chabot-Roy, A-N Pelletier, C Beauchamp, K Hardy and S Lesage

Genes and Immunity (2014) 15, 263; doi:10.1038/gene.2014.15

Correction to: Genes and Immunity (2014) 15, 82-87; doi:10.1038/ gene.2013.65; published online 16 January 2014

Since the publication of this paper, the authors have noted that reference 52 is a retracted paper. They wish to replace this with the following paper:
Peterson DA, DiPaolo RJ, Kanagawa O, Unanue ER. Quantitative analysis of the $T$ cell repertoire that escapes negative selection. Immunity 1999; 11: 453-462.

The authors apologise for any inconvenience caused. 